\title{
The Integration of Lecturers' Professionalism and Intelligence with Environment Insight
}

\author{
Sunarto $^{1}$, E. Handayani Tyas ${ }^{2}$, Lamhot Naibaho ${ }^{3}$, Elferida Sormin ${ }^{4}$, Bernadetha Nadeak ${ }^{5}$ \\ ${ }^{1}$ Faculty of Education and Teacher Training, Biology Education Department, Universitas Kristen Indonesia \\ ${ }^{2,5}$ Postgraduate Program, Magister of Education Management, Universitas Kristen Indonesia \\ ${ }^{3}$ Faculty of Education and Teacher Training, English Education Department, Universitas Kristen Indonesia \\ ${ }^{4}$ Faculty of Education and Teacher Training, Chemistry Education Department, Universitas Kristen Indonesia
}

\begin{abstract}
:
This research is about the integration of lecturers' professionalism and intelligence with the lecturers' environment insight. It was done in order to find out the relationship between lecturers' professionalism with lecturers environment insight and the relationship between lecturers' intelligence with lecturers environment insight. This research was done at the Christian University of Indonesia. The respondents of the research were 96 lecturers who were taken randomly out of 335 lectures. The research results show that there are positive relationships between lecturers' professionalism with environmental insight and lecturers' intelligence with environmental insight. It is concluded that the higher the lecturers' professionalism and intelligence, the higher is the lecturers' environment insight.
\end{abstract}

Keywords:

professionalism, intelligence, environment insight, lecturers

Article Received: 18 October 2020, Revised: 3 November 2020, Accepted: 24 December 2020

\section{INTRODUCTION}

Environmental issues have increasingly become the world's spotlight, especially by environmentalists. The worsening environmental damage has made some people worry about the survival of humans and other creatures on this earth, various types of natural events such as floods, landslides, forest fires, contaminated water, air, loss of some endangered species, rare plants and global warming, as evidence of the increasingly damaged environment on this earth $[1 ; 2]$. Damage to the natural environment will worsen if people do not immediately change their behaviour that is insightful towards their environment [3; 4].

The deteriorating quality of the environment is closely related to understanding the concept of the environment and human attitudes towards the environment [5]. It is hoped that environmental insight will foster positive behaviour in managing and preserving the environment. Recognizing the declining environmental conditions today will be necessary and very urgent to have the right means to convey information about environmental management and conservation [6;7]. To convey this information, it seems that educational facilities are much relied on to change environmental insight into the surrounding community. Society places lecturers in a more respectful place in their environment because it is hoped that a teacher can gain knowledge [8; 9]. It means that lecturers are obliged to educate the nation towards forming the whole Indonesian people based on Pancasila. Lecturers should be role models for the surrounding community [10; $11]$.

More than just a role model, this also shows that the teacher is still considered to exist, because until whenever the position or role of the teacher cannot be replaced even with a sophisticated machine, the lecturers' job concerns behaviour development $[12 ; 13 ; 14]$. The university's success in shaping the lecturers environmentally sound behaviour plays a critical role because a teacher acts as a facilitator to instil environmental insight their students $[15 ; 16]$. It means that a teacher must prepare himself as best as possible to realize his duties and responsibilities. Because lecturers are role models or some people interpret lecturers as trusted and imitated, then absolutely a teacher must first have insightful behaviour towards their environment. How will their students or the community have behavioural attitudes towards their environment if the lecturers as the community's role model do not have environment insight? [17; 18]

Lecturers who are supposed to have environment behaviour such as a) maintaining 
cleanliness; b) maintaining the beauty of the environment; c) preventing environmental damage; d) utilizing natural resources and e) maintaining sustainable natural resources. Based on the survey there are still $18 \%$ lecturers who do not have the habit of maintaining cleanliness, $18 \%$ lecturers have not maintained the beauty of the environment, $35 \%$ lecturers have not prevented environmental damage, $42 \%$ of lecturers have not saved the use of natural resources and $71 \%$ have not maintained sustainable natural resources or more than $30 \%$ of lecturers do not have environmental-oriented behaviour as mentioned above, so there is a need for efforts to improve insightful behaviour of lecturers $[19 ; 20 ; 21]$.

Improving the visionary behaviour of a lecturers' environment cannot be done in a hurry, but must be done through wise thoughts and actions so that lecturers have the knowledge and provide examples and role models in the surrounding community [22; 23]. Improving the environmentally aware behaviour of a teacher must be done continuously with the development of technology. Improving environmental insight behaviour for a teacher will not go away with various factors both from within the individual himself and from outside (environment). Lecturers are responsible for teaching and instilling values, attitudes and behaviours in students and the community [24]. Performing the task, somebody must need the abilities and personalities are required [25]. Based on this, it is necessary to try a study to reveal the relationship between lecturers' intelligence and professionalism with the lecturers' environment insight at the Christian University of Indonesia. Based on the background description, the following problems can be identified: a) is there any relationship between lecturers' professionalism and lecturers' environment insight? Furthermore, b) is there any relationship between lecturers' intelligence with lecturers environment insight?. This research is limited to intelligence, lecturers' professionalism, and environment at the Christian University of Indonesia.

\section{THEORETICAL REVIEW,}

Environmental insightful is defined as the result of a person's actions that are directed continuously and tend to be continued due to the situation and conditions they are facing. All human behaviour is determined consciously or not. The three basic assumptions are: 1) the behaviour occurs according to the law; 2) the behaviour cannot be explained by psychic mechanisms such as ideas or egos but is explained only concerning observable events or situations antecedent; 3) behaviour is not determined by individual choice but determined by past, and present in the objective world participate and do not deny the existence of genetic factors (genetic endowment) and heredity in a person's behaviour $[26 ; 27 ; 28]$. Behaviour is an action performed after the result of thinking about an input that makes sense to practice [29]. Humans and their environment are inseparable and interact with each other [30]. Human interaction with the environment is a relationship of interdependence, meaning that human behaviour affects the environment; instead, it will affect human behaviour and experience itself $[31 ; 32]$.

The environment is all things, conditions, and conditions of influence in the space occupied and affect living things, including human life. Environmentally insightful behaviour is an expression of a person's positive feelings and thoughts manifested in actions to build and realize a balance between humans and other organisms [33; 34]. Environmentally visionary behaviour is closely related .with beliefs and values towards: a) use of the natural environment; b) concern for the environment; c) conservation; d) sacrifice to the environment; e) belief in science and technology and f) concern for economic growth. Based on the above theory, it can be concluded that environmental-aware behaviour is the action of a positive and consistent person in interacting with his environment. The indicators are a) maintaining cleanliness, b) maintaining the beauty of the environment c) preventing environmental damage, d) utilizing natural resources, and (5) maintaining sustainable natural resources $[35 ; 36 ; 37]$.

Emotional intelligence is the ability to recognize ourselves and others' feelings, the ability to motivate ourselves, and the ability to manage emotions well in one-self and relationships [38]. The emotional aspect of behaviour generally always involves three variables: emotionally stimulating stimuli, physiological changes that occur when experiencing emotions, and expression patterns of emotional experiences $[39 ; 40]$. Furthermore, intelligence is the ability to perceive (feel), understand and effectively apply emotional power 
and sensitivity as a source of energy for information, connections and human influence. Human emotions are areas of deep feelings, hidden instincts, and emotional sensations. If trusted and respected, intelligence provides a more intimate understanding of oneself and others.

\section{METHODOLOGY}

This study was a quantitative study with survey design [41; 42]. It was done at the Christian University of Indonesia. It was done within three months, from September to December 2019. The respondent of this study was 96 lecturers who are taken randomly out of 335 lectures. The data technique analysis used is the correlation analysis technique to see the integration between lecturers' professionalism with environmental insight, the integration between the lecturers' intelligence and environmental insight and the integration between lecturers' professionalism and intelligence with environmental insight. The data of the research were analyzed using SPSS Ver. 16.0.

\section{RESULTS AND DISCUSSION}

After the data taken were analyzed, then it is known that the results of this study show a positive relationship between 1) Lecturers' professionalism with environmental insight; and 2) Lecturers' intelligence with environmental insight. By paying attention to the form of the relationship of independent variables with bound variables in the form of functional relationships, then it is known that the lecturers' professionalism and intelligence formed lecturers' environmental insight.

The functional relationship between lecturers' intelligence with environmental insight contains the meaning that the higher the level of lecturers intelligence, the higher the lecturers' environment insight in carrying out their duties as a lecturer. The strength of the relationship between intelligence and the lecturers' environment insight is shown. The strength of the relationship between emotional lecturers' intelligence with lecturers' environmental insight is shown by the correlation coefficient of $r_{\mathrm{y} 1}=$ 0.653 by knowing the determination coefficient $\mathrm{r}_{\mathrm{y} 1}{ }^{2}=0.423$, indicating that $44.2 \%$ of lecturers' environment insight can be generated from the presence of intelligence variables. From such thinking, it becomes clear that intelligence contributes to improving the lecturers' environment insight. Connected with the lecturers' environment insight then intelligence in which there is a desire to work to the best, intelligence will improve the lecturers' environment insight. From the elaboration above, it is concluded that the higher the intelligence, the higher the lecturers' environment insight. The functional relationship between the lecturers' professionalism with the lecturers' environment insight means that the higher the lecturers' level of professionalism, the higher the level of lecturers' environmental insight in carrying out their duties as lecturers. The strength of the relationship between lecturers' professionalism and lecturers' environment insight is shown by a correlation coefficient of $r_{\mathrm{y} 2}=0.641$ by knowing the determination coefficient $\mathrm{r}_{\mathrm{y} 2}{ }^{2}$ square $=0.402$, indicating that $38.2 \%$ of lecturers' environment insight can be generated from the lecturers' professionalism variable.

Intelligence is a person's ability to learn from experience, solve problems (problemsolving) and use knowledge effectively to adapt to new situations/conditions. This ability results from human sensing, or the result of someone knowing the object through the senses they have (eyes, nose, ears, etc.). By itself, sensing to produce knowledge is very much influenced by the intensity of attention and perception of the object. Meanwhile, professionalism reflects ability, namely having knowledge, skills, and abilities supported by experience. There are several things that characterize a professional person, namely: a) the desire to always display behaviour that can be used as a useful reference; b) trying to improve and maintain professional behaviour through the manifestation of professional behaviour; c) the manifestation is carried out in various ways, for example in the way of appearance, the way of speaking, the use of language, the body posture, and the attitude of his daily life; d) the desire to continually pursue various professional development opportunities that can enhance and improve the quality of knowledge and skills. Environmental insight is human behaviour that is a real action or act of a person to adjust to his environment in the context of a particular treatment and social settings (behaviour and social settings). A development strategy requires an open, honest atmosphere and all parties involved are always well informed. In 
development, environmental insight behaviour can be used as a medium to build a healthy human being physically and spiritually, which then with collective strength, and other human beings can build a healthy human environment.

A person with reasonable intelligence will have exemplary professionalism in doing something so that intelligence is essential to change someone's behaviour from negative to positive behaviour. Attitude is a predisposition to do or not do a particular behaviour, so that attitude is not only a purely psychic inner state of the individual (purely psychic inner state) but attitude is more of an individual process of consciousness. It means that this process occurs subjectively and uniquely in each individual, or it can be said that attitude is an essential concept in the sociopsychological component, because it tends to act and have perceptions. Attitude is the readiness to react to an object in a certain way; the form of the reaction is in the form of a positive or negative attitude. Individuals act can be determined through evaluation predisposition in the form of attitudes, but attitudes and actions are often far different. Attitude plays a vital role in shaping attitude as a whole, one of which is knowledge. Behaviour is produced by the reaction between the subject and his environment. If the object is perceived to be outside the optimal limits, the individual is stressed. Then they have to do an act of conformity, and there is a process of adjustment to the environment. By looking at the behaviour, it can show who that person is. Humans can influence the natural environment.

Therefore, human behaviour is possible to become the central point of environmental development. In this context, environmental psychology tries to study how human motivation, attitudes, feelings toward their environment. Environmental psychology is then expected to be able to predict and manipulate human behaviour for environmentally sound development. Behaviour as a way of doing actions by humans, behaviour can show who that person is. Behaviour or behaviour is expressed as a visible reaction and manifested by an organism to the situation it faces, so the behaviour is living things such as animals and humans. The relationship between humans and the environment as well as the embodiment of environmentally sound behaviour, at least we can see in the flood incident some time ago, the helping hand of various groups of people whose conscience was touched, by trying to help and overcome the physical environment can be seen as a form of environmental insight. Someone who has an adequate level of intelligence and also exemplary professionalism must have good environmental insight too. From the above elaboration, it can be summarized that lecturers' professionalism creates a pleasant vision of the university environment. Thus there will be a desire to learn better from the lecturers and all the university environment personnel and certainly will improve the performance.

\section{CONCLUSION}

The research conducted at the Christian University of Indonesia is as follows. There is a positive relationship between lecturers' intelligence with the lecturers' environment insight. This relationship can be proven from the results of regression calculations, namely with regression equation $\mathrm{Y}=85.71+0.421 \mathrm{X}_{1}$ with $\mathrm{r}_{\mathrm{y} 1}$ correlation coefficient $=0.641$. It means that the higher the lecturers' intelligence, the higher the lecturers' environment insight. Each increase of one unit of intelligence will increase the lecturers' environment insight by 0.47 units. The contribution of lecturers' intelligence variables in explaining the lecturers environment insight is $42.1 \%\left(\mathrm{r}_{\mathrm{y} 1}{ }^{2}=0.402\right)$. There is a positive relationship between lecturers' professionalism $\left(\mathrm{X}_{2}\right)$ and lecturers' environment insight $(\mathrm{Y})$. It is proven from the result of the regression calculations, namely with regression equation $\mathrm{Y}=$ $46,44+0,371 X_{2}$ with $r_{y 2}=0,641$. It means that the higher the lecturers' professionalism, the higher is the lecturers' environment insight of lecturers, so the environment-aware behaviour is also higher.

\section{REFERENCES}

[1] Goudie, A. S. (2018). Human impact on the natural environment. John Wiley \& Sons.

[2] Goudie, A. S., \& Viles, H. A. (2013). The earth transformed: an introduction to human impacts on the environment. John Wiley \& Sons.

[3] Hasnat, G. T., Kabir, M. A., \& Hossain, M. A. (2018). Major environmental issues and problems of South Asia, Particularly 
Bangladesh. Handbook of environmental materials management, 1-40.

[4] Handmer, J., Honda, Y., Kundzewicz, Z. W., Arnell, N., Benito, G., Hatfield, J., ... \& Takahashi, K. (2012). Changes in impacts of climate extremes: human systems and ecosystems. Managing the risks of extreme events and disasters to advance climate change adaptation special report of the intergovernmental panel on climate change (pp. 231-290). Intergovernmental Panel on Climate Change.

[5] Zastrow, C., \& Kirst-Ashman, K. K. (2012). Brooks/Cole Empowerment Series: Understanding Human Behavior and the Social Environment. Cengage Learning.

[6] Reed, M. S. (2008). Stakeholder participation for environmental management: a literature review. Biological Conservation, 141(10), 2417-2431.

[7] Schaltegger, S., Burritt, R., \& Petersen, H. (2017). An introduction to corporate environmental management: Striving for sustainability. Routledge.

[8] Cook-Sather, A., Bovill, C., \& Felten, P. (2014). Engaging students as partners in learning and teaching: A guide for faculty. John Wiley \& Sons.

[9] Tyas, E. H., \& Naibaho, L. (2019, November). The urgency of entrepreneurship learning in the industrial age of 4.0. In Journal of Physics: Conference Series (Vol. 1387, No. 1, p. 012032). IOP Publishing.

[10] Avis, J., \& Fisher, R. (2006). Reflections on communities of practice, on-line learning and transformation: Teachers, lecturers and trainers. Research in Post-Compulsory Education, 11(2), 141-151.

[11] Nadeak, B., Sasmoko, L. N., Sormin, E., \& Juwita, C. P. (2019). Healthy Work Culture Stimulate Performance. Indian Journal of Public Health Research \& Development, 10(6), 1385-1389.
[12] Tripp, D. (2011). Critical incidents in teaching (classic edition): Developing professional judgement. Routledge.

[13] Baker, E. L., Barton, P. E., DarlingHammond, L., Haertel, E., Ladd, H. F., Linn, R. L., ... \& Shepard, L. A. (2010). Problems with the Use of Student Test Scores to Evaluate Teachers. EPI Briefing Paper\# 278. Economic Policy Institute.

[14] Tyas, E. H., \& Sunarto, L. N. (2020). Building Superior Human Resources through Character Education.

[15] Ting, D. H., \& Cheng, C. F. C. (2017). Measuring the marginal effect of proenvironmental behaviour: Guided learning and behavioural enhancement. Journal of hospitality, leisure, sport \& tourism education, 20, 16-26.

[16] Olsen, B. (2015). Teaching what they learn, learning what they live: How teachers' personal histories shape their professional development. Routledge.

[17] McCarthy, J. (2019). Authoritarianism, populism, and the environment: Comparative experiences, insights, and perspectives.

[18] Tomietto, M., Comparcini, D., Saarikoski, M., Simonetti, V., \& Cicolini, G. (2014). Multilevel perspectives in clinical learning environments' assessment: An insight on levels involved in planning nursing education. Journal of Nursing Education and Practice, 4(12), 42-50.

[19] Kind, V. (2009). Pedagogical content knowledge in science education: perspectives and potential for progress. Studies in science education, 45(2), 169-204.

[20] Measham, T. G. (2007). Primal landscapes: Insights for education from empirical research on ways of learning about environments. International Research in Geographical \& Environmental Education, 16(4), 339-350. 
[21] Nadeak, B., \& Naibaho, L. (2019). Managing Lecturers' Competence Development at Universitas Kristen Indonesia.

[22] Griffioen, D. M. E., Doppenberg, J. J., \& Oostdam, R. J. (2018). Organizational influence on lecturers' perceptions and behaviour towards change in education. Studies in Higher Education, 43(11), 1810-1822.

[23] Elbaz, A. M., \& Haddoud, M. Y. (2017). The role of wisdom leadership in increasing job performance: Evidence from the Egyptian tourism sector. Tourism Management, 63, 66-76.

[24] Arnon, S., Orion, N., \& Carmi, N. (2015). Environmental literacy components and their promotion by institutions of higher education: an Israeli case study. Environmental Education Research, 21(7), 1029-1055.

[25] Cook-Sather, A. (2010). Students as learners and teachers: taking responsibility, transforming education, and redefining accountability. Curriculum Inquiry, 40(4), 555-575.

[26] Rothenberg, K., \& Wang, A. (2006). The scarlet gene: Behavioral genetics, criminal law, and racial and ethnic stigma. Law and Contemporary Problems, 69(1/2), 343-365.

[27] Hoff, K., \& Stiglitz, J. E. (2016). Striving for balance in economics: Towards a theory of the social determination of behaviour. The World Bank.

[28] Naibaho, L. (2014). The Role of Education and Culture in the Development of Character and Civilization of the Plural Indonesian Nation. Jurnal the Ary Suta Center Series on Strategic Management, 27(0), 69.

[29] John, P., Cotterill, S., Richardson, L., Moseley, A., Smith, G., Stoker, G., ... \& Nomura, H. (2013). Nudge, nudge, think, think: Experimenting with ways to change civic behaviour. A\&C Black.
[30] Lee, W. S., Huang, J. C., Chang, C. T., Chan, S. C., Liou, Y. S., Liao, C. S., ... \& Chen, P. H. (2020). Interaction Among Controlling Factors on Riverine DIN Export in Small Mountainous Rivers of Taiwan: Inseparable Human-Landscape System. Water, 12(11), 2981.

[31] Davis, J. L., Green, J. D., \& Reed, A. (2009). Interdependence with the environment: Commitment, interconnectedness, and environmental behaviour. Journal of environmental psychology, 29(2), 173-180.

[32] Ashford, J., \& LeCroy, C. (2009). Human behaviour in the social environment: $A$ multidimensional perspective. Nelson Education.

[33] Gifford, R., \& Nilsson, A. (2014). Personal and social factors that influence proenvironmental concern and behaviour: A review. International Journal of Psychology, 49(3), 141-157.

[34] Boiral, O., Raineri, N., \& Talbot, D. (2018). Managers' citizenship behaviours for the environment: a developmental perspective. Journal of Business Ethics, 149(2), 395-409.

[35] Nadeak, B., Sasmoko, U. E. I., Naibaho, L., Sormin, E., \& Juwita, C. P. (2019). Building Employees' Mental Health: The Correlation between Transactional Leadership and Training Program with Employees' Work Motivation at XWJ Factory. Indian Journal of Public Health Research \& Development, 10(6), 1373-1379.

[36] Hart, R. A. (2013). Children's participation: The theory and practice of involving young citizens in community development and environmental care. Routledge.

[37] Dahlmann, F., Branicki, L., \& Brammer, S. (2019). Managing carbon aspirations: The influence of corporate climate change targets on environmental performance. Journal of business ethics, 158(1), 1-24.

[38] Dhani, P., \& Sharma, T. (2016). Emotional Intelligence: History, Models and Measures. 
[39] Tyng, C. M., Amin, H. U., Saad, M. N., \& Malik, A. S. (2017). The influences of emotion on learning and memory. Frontiers in psychology, 8, 1454.

[40] Watson, R. (2015). Quantitative research. Nursing Standard, 29(31).

[41] Nadeak, B., \& Naibaho, L. (2020). Video-Based Learning on Improving Students' Learning Output. PalArch's Journal of Archaeology of Egypt/Egyptology, 17(2), 44-54.

[42] Kelley-Quon, L. I. (2018, December). Surveys: Merging, qualitative and quantitative research methods. In Seminars in pediatric surgery (Vol. 27, No. 6, pp. 361-366). WB Saunders. 